\title{
JAKARTA INTEGRATED URBAN FARM
}

\author{
Arif Rosidi, Edi Pramono Singgih, Sri Yuliani \\ Program Studi Arsitektur \\ Universitas Sebelas Maret Surakarta \\ Email: arosrosidi@gmail.com
}

\begin{abstract}
The background of the designing of Jakarta Integrated Urban Farm is the lack of Jakarta's vegetables and fruit productivity which is caused by the decreasing of it's farm field. On the other hand, farming technology has improved significantly to afford a farming activities in a small urban area. Beside those, Jakarta as one of the largest metropolitan area in South East Asia also suffers from the environment damage as the effect of global warming that had already spread worldwide. Architecture and the industries that directly involved are one of several that causes it. Green Architecture as one of architecture's discipline can be applied to minimize the damage of a building to the environment. The purpose of this designing process is a design of an integrated urban farm that can integrate among cultivation, production, research, and marketing activity, also contribute to the healing of the environment by apllied Green Architecture's principles. The design issue is how to integrate cultivation, production, research, and marketing activity on an urban farm building that applies Green Architecture's principle. The method that used is architecture designing method which consist of several stages. The conclusion is a design of an urban farm that integrate cultivation, production, research, and marketing activity, also contribute to the Jakarta's environment health by apllying energy conservation, land conservation, and water conservation.
\end{abstract}

Keywords: Cultivation, Green Architecture, Jakarta, Marketing, Production, Research, Urban Farm,

\section{PENDAHULUAN}

Jakarta merupakan ibu kota Indonesia, wilayah ini dinamakan Daerah Khusus Ibu Kota Jakarta. Kota terbesar dan terpadat di Indonesia. Sebagai ibu kota Negara, Jakarta berkembang pesat. Perkembangan yang begitu pesat di bidang ekonomi, bisnis, dan industri. Di satu sisi perkembangan yang pesat tersebut sangat menguntungkan, tapi di sisi lain tak sedikit pula masalah yang ditimbulkan. Perkembangan yang pesat mengakibatkan banyak lahan-lahan produktif berubah menjadi kawasan industri, mall, apartemen, dan perumahan.

Perkembangan Kota Jakarta menyebabkan berkurangnya lahan pertanian di Kota Jakarta. Sedikitnya lahan pertanian mengakibatnya produksi bahan makanan dari sektor pertanian semakin sedikit pula. Padahal setiap tahun kebutuhan masyarakat semakin meningkat. Dampaknya, hampir 95\% kebutuhan bahan makanan masyarakat Jakarta didatangkan dari luar kota, atau bahkan impor dari luar negeri. Sebagai negara agraris Indonesia tak mampu memenuhi kebutuhan bahan makanan yang merupakan produk pertanian.
Berdasarkan data BPS Provinsi Jakarta tahun 2012, luas lahan pertanian di Jakarta setiap tahun semakin menyempit. Dapat kita lihat pada gambar di bawah :

Tabel 1. Luas Lahan Pertanian Sayuran di Kota Jakarta

\begin{tabular}{|l|l|l|l|l|l|}
\hline Sayuran & 2008 & 2009 & 2010 & 2011 & 2012 \\
\hline Kangkung & 1136 & 1284 & 1257 & 1008 & 563 \\
& $\mathrm{Ha}$ & $\mathrm{Ha}$ & $\mathrm{Ha}$ & $\mathrm{Ha}$ & $\mathrm{Ha}$ \\
\hline Bayam & 858 & 1014 & 1045 & 728 & 377 \\
& $\mathrm{Ha}$ & $\mathrm{Ha}$ & $\mathrm{Ha}$ & $\mathrm{Ha}$ & $\mathrm{Ha}$ \\
\hline Sawi & 591 & 824 & 983 & 722 & 303 \\
& $\mathrm{Ha}$ & $\mathrm{Ha}$ & $\mathrm{Ha}$ & $\mathrm{Ha}$ & $\mathrm{Ha}$ \\
\hline Lainnya & $39 \mathrm{Ha}$ & $45 \mathrm{Ha}$ & $39 \mathrm{Ha}$ & $29 \mathrm{Ha}$ & $3 \mathrm{Ha}$ \\
\hline
\end{tabular}

(BPS DKI Jakarta)

Pada Tabel 1 di atas menunjukkan data penurunan jumlah lahan pertanian sayuran di Kota Jakarta. Setiap tahun jumlahnya terus menurun, terutama mulai 2010 - 2012 terjadi penurunan yang cukup drastis.

Kemajuan teknologi yang begitu pesat di bidang pertanian akhir-akhir ini memungkinkan metode budidaya tanaman yang berbeda dengan metode budidaya konvensional. Pertanian di dalam gedung, pertanian di atas atap bangunan, bahkan 
pertanian di bawah tanah atau basement bangunan pun ada. Metode budidaya pun beragam, hidroponik, akuaponik, pertaian vertikal, green house, growing chamber, dan lain-lain.

Pemanasan global (Inggris: global warming) adalah suatu proses meningkatnya suhu rata-rata atmosfer, laut, dan daratan Bumi. Suhu rata-rata global pada permukaan Bumi telah meningkat $0.74 \pm 0.18{ }^{\circ} \mathrm{C}(1.33 \pm$ $\left.0.32{ }^{\circ} \mathrm{F}\right)$ selama seratus tahun terakhir. Meningkatnya suhu global diperkirakan akan menyebabkan perubahan-perubahan yang lain seperti naiknya permukaan air laut, meningkatnya intensitas fenomena cuaca yang ekstrem, serta perubahan jumlah dan pola presipitasi. Akibat-akibat pemanasan global yang lain adalah terpengaruhnya hasil pertanian, hilangnya gletser, dan punahnya berbagai jenis hewan.

Dalam dunia arsitektur, konsep Arsitektur Hijau yang ramah lingkungan mulai banyak diterapkan guna mengurangi dampak Global Warming. Arsitektur Hijau yang menerapkan prinsip-prinsip yang ramah lingkungan seperti hemat energi, konservasi air, konservasi lahan, pemanfaatan material lokal, dan lain sebagainya. Bangunanbangunan baru seharusnya mutlak menerapkan konsep Arsitektur Hijau ini sebagai upaya dunia arsitektur berkontribusi mencegah Global Warming.

\section{METODE}

Metode yang digunakan adalah metode perancangan arsitektur yang terdiri dari:

1. Analisis Peruangan

Menganalisis kegiatan yang diwadahi, sehingga didapatkan data kebutuhan ruang berikut dengan besarannya yang dihitung memakai standar-standar perhitungan yang diakui di disiplin ilmu arsitektur.

2. Analisis Tapak

Menganilis tapak berdasarkan data-data eksisting tapak di lapangan.

3. Analisis Massa dan Gubahan Massa

Menganalisis bentuk massa dan gubahan massa berdasarkan hasil dari analisis tapak.

4. Analisis Arsitektur Hijau

Menganalisis penerapan prinsip Arsitektur Hijau ke dalam bangunan berdasarkan hasil analisis tapak dan analisis bentuk massa dan gubahan massa.

\section{ANALISIS}

\subsection{Analisis Peruangan}

Kegiatan yang diwadahi didasarkan pada kegiatan umum Urban Farm yang dikembangkan dengan kebutuhan ruang yang mewadahi kegiatan masyarakat urban, sehingga pengelompokan kegiatan terbagi sesuai luas yang dibutuhkan, seperti pada Tabel 2.

Tabel 2. Kebutuhan Ruang Makro

\begin{tabular}{|l|l|}
\hline \multicolumn{1}{|c|}{ Kelompok Kegiatan } & \multicolumn{1}{c|}{ Luas } \\
\hline Penerima & $209 \mathrm{~m} 2$ \\
\hline Budidaya Sayur & $14.040 \mathrm{~m} 2$ \\
\hline Budidaya Buah & $14.040 \mathrm{~m} 2$ \\
\hline Produksi Sayur & $617 \mathrm{~m} 2$ \\
\hline Produksi Buah & $617 \mathrm{~m} 2$ \\
\hline Penelitian Benih & $537 \mathrm{~m} 2$ \\
\hline Penelitian Budidaya & $537 \mathrm{~m} 2$ \\
\hline Penelitian Produksi & $537 \mathrm{~m} 2$ \\
\hline Supermarket & $3500 \mathrm{~m} 2$ \\
\hline Restoran & $3500 \mathrm{~m} 2$ \\
\hline Pengelola & $760 \mathrm{~m} 2$ \\
\hline Parkir dan Keamanan & $1987 \mathrm{~m} 2$ \\
\hline Distribusi Barang & $319 \mathrm{~m} 2$ \\
\hline Utilitas Bangunan & $690 \mathrm{~m} 2$ \\
\hline
\end{tabular}

(Arif Rosidi, 2016)

\subsection{Analisis Lokasi}

Selain menentukan lokasi yang strategis, memilih tapak dengan kondisi yang mendukung keberadaan Urban Farm ini sangat menentukan prospek bangunan tersebut.

\subsubsection{Tujuan}

Lokasi yang sesuai dengan Urban Farm

\subsubsection{Dasar Pertimbangan}

Posisi tapak strategis untuk kepentingan bisnis Urban Farm, luasan tapak dapat menampung seluruh kebutuhan ruang yang direncanakan.

\subsection{Analisis Pencapaian}

Pencapaian ke dalam bangunan harus mudah diakses, mudah dilihat dan memiliki sirkulasi yang aman akan menstimulus orang untuk masuk dalam area bangunan.

\subsubsection{Tujuan}


Main entrane, side entrance, dan service entrance

\subsubsection{Dasar Pertimbangan}

Kemudahan akses, sirkulasi tapak yang aksesibel, arus kendaraan dan potensi jalan, tingkat keamanan.

\subsubsection{Proses Analisis}

Main Entrance (ME)

Mudah dijangkau dan terlihat dengan jelas. Menghadap langsung ke arah jalan untuk kemudahan sirkulasi kendaraan masuk dan ke luar tapak.

Side Entrance (SE)

Tidak mengganggu keberadaan ME. Membantu sirkulasi pengelola.

Service Entrance

Tidak mengganggu keberadaan ME dan SE. Memudahkan sirkulasi keluar masuk barang.

\subsection{Analisis View dan Orientasi Bangunan \\ 3.4.1 Tujuan}

Orientasi bangunan dengan view ke luar bangunan yang menarik dan sesuai dengan fungsi Jakarta Integrated Urban Farm.

\subsubsection{Dasar Pertimbangan}

Potensi view lingkungan sekitar tapak. Pola kegiatan lingkungan dan kota.

\subsection{Analisis Potensi Matahari}

\subsubsection{Tujuan}

Zonasi pada tapak berdasarkan intensitas cahaya matahari di dalam tapak.

\subsubsection{Dasar Pertimbangan}

Peredaran harian matahari dan pembayangan bangunan-bangunan bertingkat sekitar tapak di dalam tapak.

\subsection{Analisis Potensi Angin}

\subsubsection{Tujuan}

Zonasi pada tapak berdasarkan potensi angin yang masuk ke dalam tapak.

\subsubsection{Dasar Pertimbangan}

Arah datang angin, sifat angin, dan posisi bangunan bertingkat di sekitar tapak.
3.7 Analisis Pemintakatan (Penzoningan) Pemintakatan berdasarkan sifat kegiatan dan keadaan dalam tapak dilakukan sebagai acuan dalam penataan peruangan.

\subsubsection{Tujuan}

Mintakat (zoning) berdasarkan sifat kegiatan dan keadaan pada tapak.

\subsubsection{Dasar Pertimbangan}

Analisis peruangan, analisis pengolahan tapak.

\subsubsection{Proses Analisis}

Persyaratan ruang, berdasarkan kelompok kegiatan dan analisis pengolahan tapak.

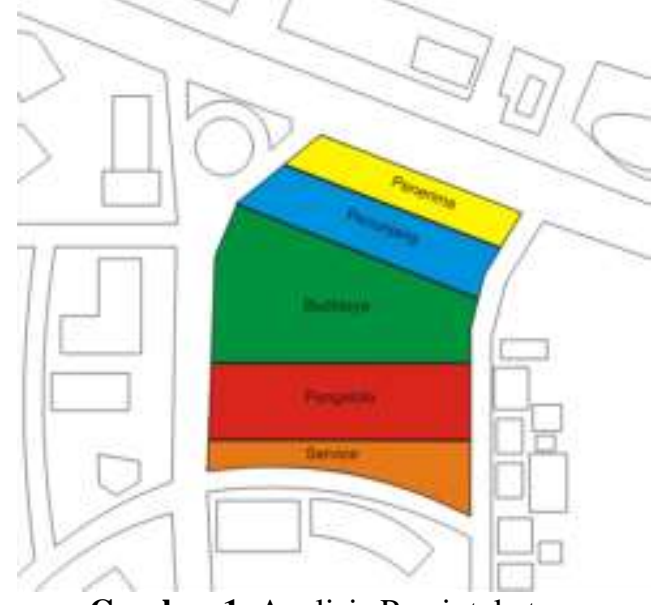

Gambar 1. Analisis Pemintakatan

Pada Gambar 1 di atas terlihat pemintakatan pada tapak terbagi atas penerima, penunjang, budidaya, pengelola, dan servis.

\subsection{Analisis Bentuk dan Gubahan Massa}

\subsubsection{Analisis Bentuk Massa}

Bentuk massa menggunakan bentuk-bentuk dasar bangun ruang yang sederhana, kemudian bentuk-bentuk tersebut diolah menggunakan teknik tektonik (mencungkil/melubangi) dan stereotomik (menumpuk).

\subsubsection{Analisis Gubahan Massa \\ 3.8.2.1 Gubahan Massa Utama}




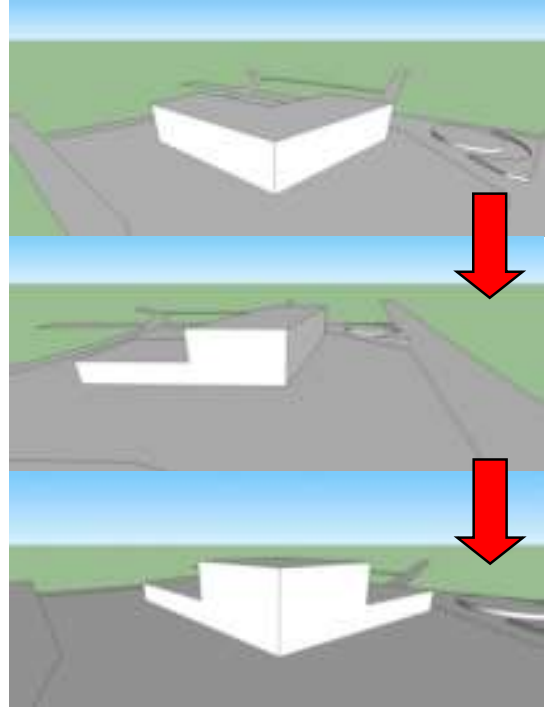

Gambar 2. Gubahan Massa Utama

Pada Gambar 2 terlihat proses analisis gubahan massa bangunan utama. Massa bangunan utama terbentuk dari sebuah balok yang berbentuk L. Kemudian balok L tersebut dibentuk sedemikian rupa dengan teknik tektonik.

\subsubsection{Gubahan Massa Budidaya}

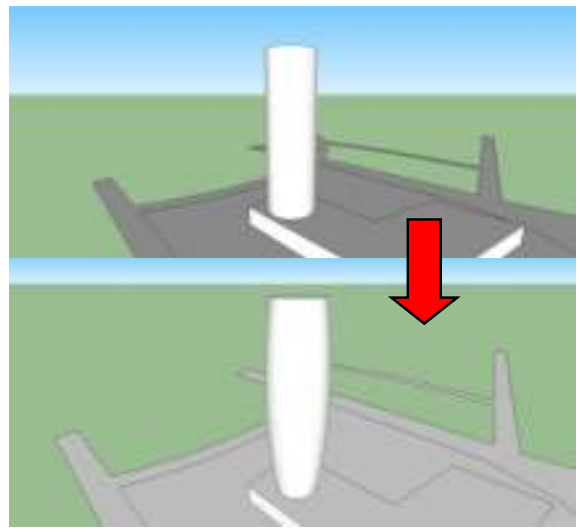

Gambar 3. Gubahan Massa Budidaya

Pada Gambar 3 terlihat proses analisis gubahan massa bangunan budidaya. Massa budidaya memakai dasar silinder yang diletakkan di atas massa bangunan utama. Kemudian bagian tengah silinder sedikit digembungkan dengan memperbesar diameter lingkarannya.

\subsubsection{Analisis Gabungan Massa}

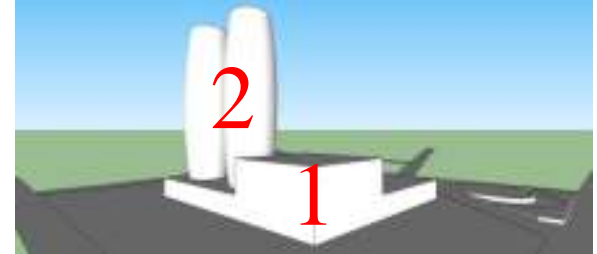

Gambar 4. Gabungan Massa

Pada Gambar 4 di atas merupakan gabungan massa bangunan. Massa nomer 1 adalah massa bangunan utama. Massa nomer 2 adalah massa bangunan budidaya.

\subsection{Analisa Arsitektur Hijau}

Arsitektur Hijau (Green Architecture) adalah wawasan arsitektur yang memadukan tidak saja nilai-nilai arsitektur umum (kekuatan, fungsi, kenyamanan, biaya, estetika) tetapi juga dimensi-dimensi lingkungan berlandaskan kepedulian tentang konservasi lingkungan global alami dengan penekanan pada efisiensi energi (energy-efficient), pola berkelanjutan (sustainable) dan pendekatan holistik (holistic approach) untuk meminimalkan kerusakankerusakan yang akan terjadi (Priatman, 2006).

\subsubsection{Konservasi Energi}

\section{Solar Cell}

Sel surya terbuat dari potongan silikon yang sangat kecil dengan dilapisi bahan kimia khusus untuk membentuk dasar darisel surya. Sel surya pada umumnya memiliki ketebalan minimum $0,3 \mathrm{~mm}$ yang terbuat dari irisan bahan semikonduktor dengan kutub positif dan negatif. Tiap sel surya biasanya menghasilkan tegangan 0,5 volt. Sel surya merupakan elemen aktif (Semikonduktor) yang memanfaatkan efek photovoltaic untuk merubah energi surya menjadi energi listrik.

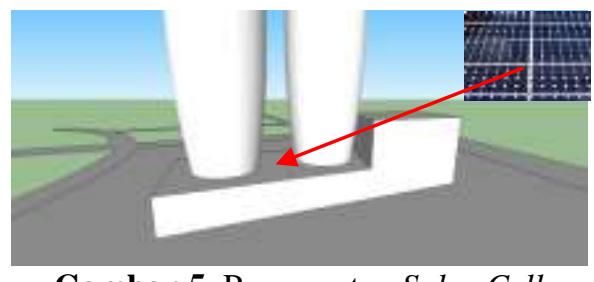

Gambar 5. Penempatan Solar Cell

Gambar 5 di atas menunjukan penempatan solar cell. Solar Cell ditempatkan di atap bangunan massa utama yang relatif terbuka dan terkena cahaya matahari hampir sepanjang 
hari. Hal itu dapat memaksimalkan energi yang dapat diproduksi Solar cell.

\section{Wind Turbine}

Wind Turbine atau Turbin Angin adalah kincir angin yang digunakan untuk membangkitkan tenaga listrik. Kini turbin angin lebih banyak digunakan untuk mengakomodasi kebutuhan listrik masyarakat, dengan menggunakan prinsip konversi energi dan menggunakan sumber daya alam yang dapat diperbaharui yaitu angin.

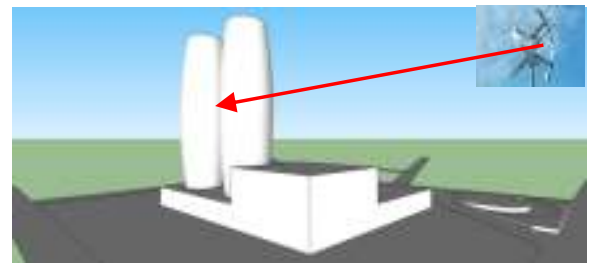

Gambar 6. Penempatan Wind Turbine

Gambar 6 menjelaskan letak penempatan Wind Turbine. Wind Turbine ditempatkan di beberapa bagian dinding massa bangunan budidaya. Massa bangunan budidaya yang merupakan bangunan high rise memungkinkan wind turbine dapat berfungsi maksimal menghasilkan listrik dari energi angin lingkungan sekitar.

\section{Natural Day-Lighting}

Cahaya Matahari merupakan salah satu kebutuhan pokok tanaman dalam rangka berfotosintesis untuk menghasilkan makanan yang diperlukan pertumbuhan tanaman. Pemanfaatan cahaya matahari yang sebesar-besarnya dapat mengurangi penggunaan energi listrik untuk menyalakan lampu. Salah satu caranya adalah dengan membuat bukaan-bukaan yang lebar dan tinggi sehingga cahaya matahari dapat masuk maksimal kedalam ruangan.

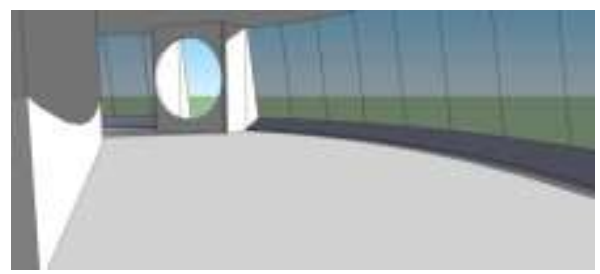

Gambar 7. Bukaan yang Lebar dan Tinggi Pada Bangunan
Dari Gambar 7 di atas bisa dilihat bahwa bukaan yang lebar dan tinggi dengan material kaca dapat memasukkan cahaya matahari yang mampu menerangi hampir selurung ruangan. Hal itu berakibat pada penggunaan cahaya buatan untuk memenuhi kebutuhan tanaman dapat dikurangi.

\subsubsection{Konservasi Lahan}

1. Ruang terbuka hijau

Jakarta Integrated Urban Farm yang direncanakan akan memanfaatkan "tanamannya" sebagai sarana untuk memulihkan kembali lingkungan hijau yang telah hilang atau rusak dengan menambahan prosentase nilai RTH pada tapak yaitu lebih dari $30 \%$.

2. Biopori

Lubang resapan Biopori adalah lubang silindris yang dibuat secara vertikal ke dalam tanah sebagai metode resapan air yang ditujukan untuk mengatasi genangan air dengan cara meningkatkan daya resap air pada tanah.

\subsubsection{Konservasi Air}

Rain water harvesting atau memanen air hujan merupakan alternatif sumber air yang sudah dipraktekkan selama berabad-abad di berbagai negara yang sering mengalami kekurangan air (ChaoHsien \& Yao-Lung, 2004). Air hujan yang dipanen dapat digunakan untuk multi tujuan seperti menyiram tanaman, mencuci, mandi dan bahkan dapat digunakan untuk memasak jika kualitas air tersebut memenuhi standar kesehatan (Worm \& van Hattum, 2006).

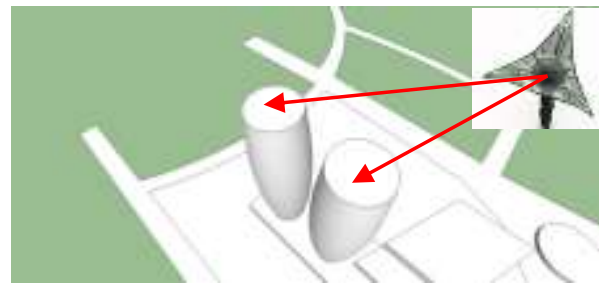

Gambar 8. Penempatan Rain Water Catcher

Gambar 8 menjelaskan penempatan Rain Water Catcher. Rain Water Catcher sebagai 
alat untuk mengumpulkan air hujan ditempatkan di atas atap massa budidaya. Karena posisinya yang paling tinggi di antara massa yang lain.

\section{KESIMPULAN (KONSEP DESAIN)}

Konsep rancangan Jakarta Integrated Urban Farm adalah pertanian urban yang mengintegrasikan fungsi budidaya, produksi, penelitian, dan pemasaran serta berkontribusi terhadap perbaikan lingkungan Kota Jakarta dengan menerapkan konservasi energi, konservasi lahan, dan konservasi air. Ruangruang dalam Jakarta Integrated Urban Farm dibagi berdasarkan kelompok kegiatan budidaya, produksi, penelitian, dan pemasaran (Gambar 9). Walaupun terbagi sesuai dengan kelompok kegiatannya, ruang-ruang tersebut tetap terintegrasi satu dengan yang lain karena penerapan sirkulasi yang benar. Konservasi energi dengan menggunakan solar cell (Gambar 10) dan wind turbine (Gambar 11) untuk mengubah energi matahari dan angin dari lingkungan sekitar menjadi energi listrik, serta bukaan yang lebar terutama pada ruangruang budidaya mampu mengurangi penggunaan energi listrik (Gambar 12 dan 13). Konservasi lahan dengan memanfaatkan lebih dari 30\% tapak sebagai Ruang Terbuka Hijau yang ditanami tanaman buah outdoor dan Biopori di sela-sela tanaman buah outdoor tersebut (Gambar 14). Konservasi air dengan menggunakan rain water cather untuk mengumpulkan air hujan yang kemudian bisa dimanfaatkan untuk budidaya sistem hidroponik (Gambar 15). Konservasi air juga diterapkan dalam pengolahan air limbah grey water sehingga hasilnya bisa dimanfaatkan kembali.

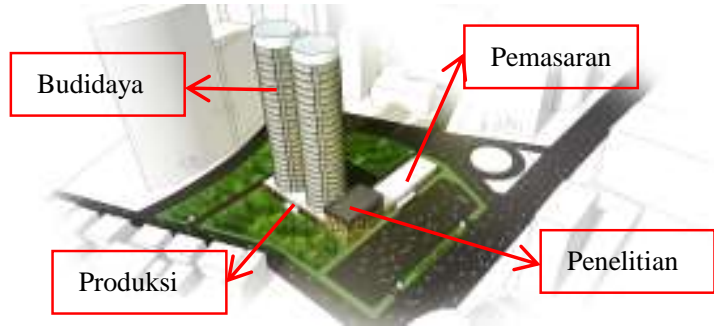

Gambar 9. Pembagian Kelompok Kegiatan

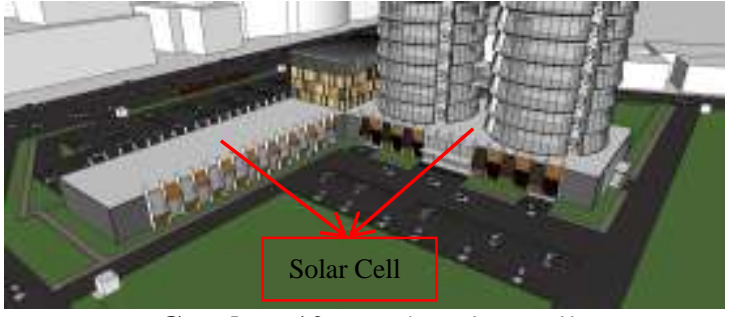

Gambar 10. Letak Solar Cell

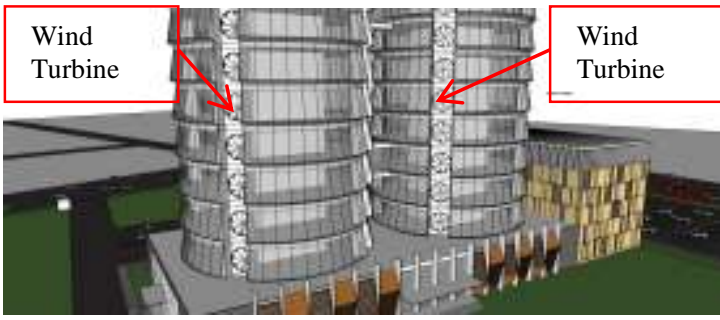

Gambar 11. Letak Wind Turbine

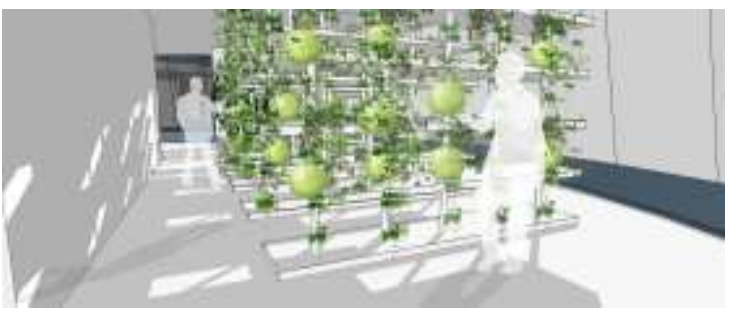

Gambar 12. Ruang Budidaya Buah dengan Bukaan yang Lebar

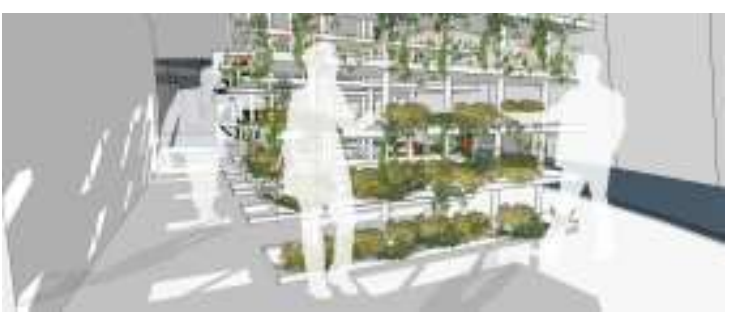

Gambar 13. Ruang Budidaya Sayur dengan Bukaan yang Lebar

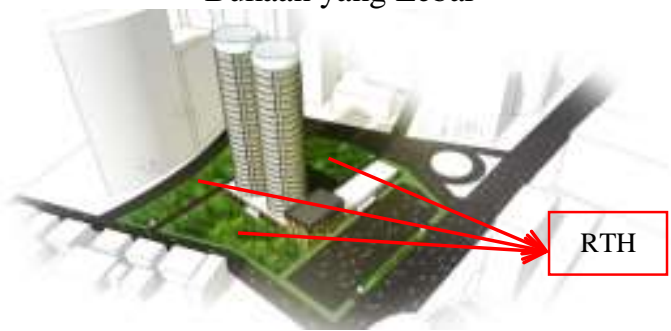

Gambar 14. Ruang Terbuka Hijau

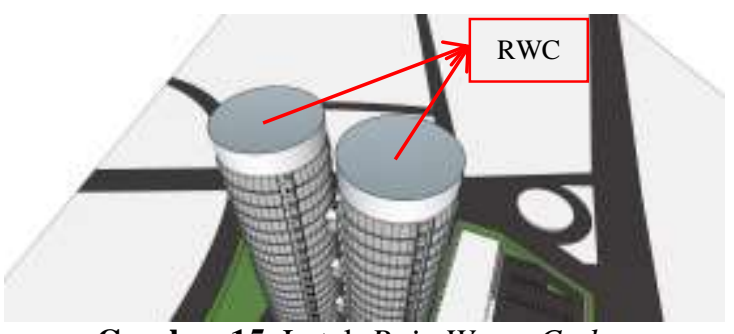

Gambar 15. Letak Rain Water Cather 


\section{REFERENSI}

Chao-Hsien, Liaw and Yao-Lung, Tsai. 2004, Optimum Storage Volume of Rooftop Rain Water Harvesting System for Domestic Use.

Worm, Janette \& van Hattum, Tim, 2006, Rainwater Harvesting For Domestic Use.

Priatman, Jimmy, 2006, "Energy-efficient Architecture" Paradigma dan Manifestasi Arsitektur Hijau 